\title{
Soil Preparation and Liming for Vegetable Gardens ${ }^{1}$
}

\author{
James M. Stephens and Guodong Liu²
}

Probably the most physical part of vegetable gardening is preparing the soil for planting. In large gardens, mechanical equipment, such as rototillers or tractor-drawn plows, often is necessary, and it may be practical to rent such equipment or hire someone. However, in smaller gardens, the task can be accomplished with a spade, spading fork, or shovel. Much depends on the type of roots and vegetation that must be removed.

Turn the ground about 3 weeks before planting, when the soil is dry enough to work. Turn the soil completely over when spading. Many gardeners practice "double-digging" in order to prepare a deeper root zone. To "double-dig," shovel off a 12-inch layer of soil, turn the bottom 12-inch layer, then replace the topsoil.

Weeds, cover crops, and added organic matter, such as compost and animal manure, may all be spaded under at the same time. Sufficient time must be allowed for the freshly turned-under organic material to decompose and become fairly well rotted before seeds are planted. Woody plant materials, such as roots, sticks, and dried dog-fennel stalks, are best removed from the garden rather than cut into the soil. Likewise, perennial grass and weed pests should be removed whenever possible to eliminate recurring problems.

Break all clods and level with a rake, or harrow the soil soon after turning to maintain good soil texture and prevent excessive drying. For small-seeded crops such as carrots, and for all crops to a certain extent, a finely pulverized surface ensures easier planting, better germination, and a more even stand. A plank drag may be used to make the soil ready for planting in larger gardens. A hand rake may serve the same purpose in smaller plots.

\section{Soil Reaction and Lime}

In many gardens, soil preparation includes the application of a liming material if a soil test shows it is needed. Most vegetables grow best in a soil that has a $\mathrm{pH}$ between 5.8 and 6.3 (slightly acidic). Soil $\mathrm{pH}$ range for optimal vegetable growth is species dependent (Liu and Hanlon 2012). The symbol " $\mathrm{pH}$ " and the figures accompanying it are used to express the degree of soil acidity. A soil with a $\mathrm{pH}$ of 7.0 is neutral, while one with a $\mathrm{pH}$ of 6.9 or below is acidic or "sour," and one with a $\mathrm{pH}$ of 7.1 or above is alkaline or "sweet" (Table 1).

Lime properly applied to extremely acidic soils increases production of most vegetables. The main functions of lime are to neutralize soil acidity, supply nutrients-mainly calcium - to the soil, and bring micronutrients into usable form (Liu and Hanlon 2012). A well-limed soil helps to avoid such problems as blossom-end rot of tomatoes, which is believed to be a calcium deficiency disorder (de Freitas et al. 2012). Apply liming materials only if a soil test indicates a need for them. Your county UF/IFAS Extension office can provide information about how to have your soil tested. The old adage, "Don't guess, soil test!" has true meaning.

Too much lime in the soil may be just as bad as too little. If soils are highly alkaline, pay special attention to the inclusion of minor elements in fertilizer mixes. Sulfur is

1. This document is HS503, one of a series of the Horticultural Sciences Department, UF/IFAS Extension. Original publication date October 1998. Revised June 2013. Visit the EDIS website at http://edis.ifas.ufl.edu.

2. James M. Stephens, professor emeritus, and Guodong Liu, assistant professor, Horticultural Sciences Department, UF/IFAS Extension, Gainesville, FL 32611.

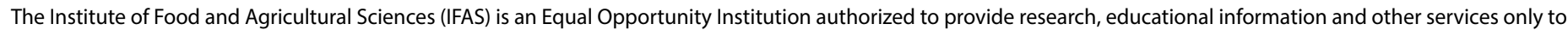

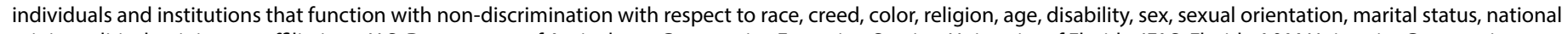
origin, political opinions or affiliations. U.S. Department of Agriculture, Cooperative Extension Service, University of Florida, IFAS, Florida A\&M University Cooperative

Extension Program, and Boards of County Commissioners Cooperating. Nick T. Place, Dean 
suggested to reduce alkalinity in overlimed soils. Generally, 1-2 pounds per 100 square feet is adequate. However, in soils with a native $\mathrm{pH}$ of more than 7.0, applying sulfur is of little benefit.

Table 1. USDA Natural Resources Conservation Service soil pH range classifications

\begin{tabular}{|l|l|}
\hline Term & pH range \\
\hline Ultra acid & $<3.5$ \\
\hline Extreme acid & $3.5-4.4$ \\
\hline Very strong acid & $4.5-5.0$ \\
\hline Strong acid & $5.1-5.5$ \\
\hline Moderate acid & $5.6-6.0$ \\
\hline Slight acid & $6.1-6.5$ \\
\hline Neutral & $6.6-7.3$ \\
\hline Slightly alkaline & $7.4-7.8$ \\
\hline Moderately alkaline & $7.9-8.4$ \\
\hline Strongly alkaline & $8.5-9.0$ \\
\hline Very strongly alkaline & $>9.0$ \\
\hline (Source: Soil Survey Division Staff 1993) \\
\hline
\end{tabular}

Liming materials and the amount to apply depend upon a number of factors, including the soil reaction $(\mathrm{pH})$, crop species planted, and soil type. Often it is necessary to talk with a consultant or advisor to determine the proper liming program for garden soil, but in general, a reaction below pH 5.5 indicates a need for lime, and $2-3$ pounds of dolomitic lime per 100 square feet is a fairly effective application to start a remedial program.

Agricultural limestone, which contains mostly calcium carbonate, may be used. However, dolomite is a good liming material because of its magnesium content, which is essential for plant growth and development. Owing to its relatively slow reaction, it should be applied well ahead of planting (2-3 months). Hydrated lime may be used if a quick-acting material is required. It may be applied 2 weeks or more before planting, provided it is mixed well with the soil. Use at three-fourths the above rate for dolomite.

The lime should be spread evenly throughout the garden before plowing or spading it into the soil to a depth of 6 inches. Water the soil to promote the chemical reaction.

When a soil test has established a need for liming, lime may be applied close to planting (a day or two) without detriment; however, it will be several weeks before the benefits of liming are visible.

\section{Other Considerations at Soil Preparation Time}

Fertilizing - When preparing the soil for planting, consider the fertilizer needs of the soil and plants. Refer to Fertilizing the Garden (http://edis.ifas.ufl.edu/vh025) and Producing Garden Vegetables with Organic Soil Amendments (http://edis.ifas.ufl.edu/mg323).

Bedding - Elevated soil beds may be needed where puddling or flooding might cause root damage. Also, beds often are beneficial to root crops, such as carrots and potatoes. Otherwise, it may be advantageous to plant seeds on a level surface to ensure moisture in the root zone. Where beds are needed, they can be constructed with a hoe, wheel plow, or garden tractor in multiple rows or in raised 4-foot-wide beds. Usually, a bed height of 6-8 inches is sufficient.

Wide-row borders - Wood and other materials, such as plastic and concrete, are often used to confine the soil within a wide-row system. Treated lumber, which resists decay, may be used with vegetables, although many organic gardeners refrain from using it because of a concern that the preservative may be harmful to health. There have been no conclusive studies to show that treated lumber poses any real danger.

\section{References}

de Freitas, S. T., A. K. Handa, Q. Wu, S. Park, and E. J. Mitcham. 2012. "Role of Pectin Methylesterases in Cellular Calcium Distribution and Blossom-End Rot Development in Tomato Fruit." The Plant Journal 71: 824-835. doi: 10.1111/j.1365-313X.2012.05034.x http://onlinelibrary. wiley.com/doi/10.1111/j.1365-313X.2012.05034.x/pdf.

Liu, G. D., and E. Hanlon. 2012. Soil pH Range for Optimum Commercial Vegetable Production. HS1207. Gainesville: University of Florida Institute of Food and Agricultural Sciences. http://edis.ifas.ufl.edu/hs1207.

Soil Survey Division Staff. 1993. "Soil Survey Manual, Chapter 3: Examination and Description of Soils." USDA Natural Resources Conservation Service. Accessed May 16, 2013. http://soils.usda.gov/technical/manual/contents/ chapter3.html. 